Afridi, F.E.A., Jan, S., Ayaz, B., Irfan, M., Khan, Q. (2021). The impact of institutional factors on social entrepreneurship activities: an empirical evidence from Pakistan. Amazonia Investiga, 10(43), 41-48. https://doi.org/10.34069/AI/2021.43.07.4

\title{
The impact of institutional factors on social entrepreneurship activities: an empirical evidence from Pakistan
}

$$
\text { ثبوت. تجرباتى ايك سـ ياكستان :اثرات كح عو امل جاتى اداره ير سركرميون كاروبارى سماجى }
$$

\begin{abstract}
Social entrepreneurship has soon recognized as important factor in socio-economic development. So far little research has been done in the context of developing young countries like Pakistan. This study investigate how institutional factors affect social entrepreneurial activities in Pakistan. Data from GEM were used for analysis. Due to the binary nature of the dependent variables, we used logistic regression models to test the hypothesis using the ReLogit estimation technique. This study generates key important results. The findings indicated that informal institutional factors influence more the likelihood of being social entrepreneur than formal institutional factors. The empirical findings provide useful information for government policies on promoting social entrepreneurship.
\end{abstract}

Keywords: Social enterprise, entrepreneurship, institutional economics, Institutional theory.
خلاصس

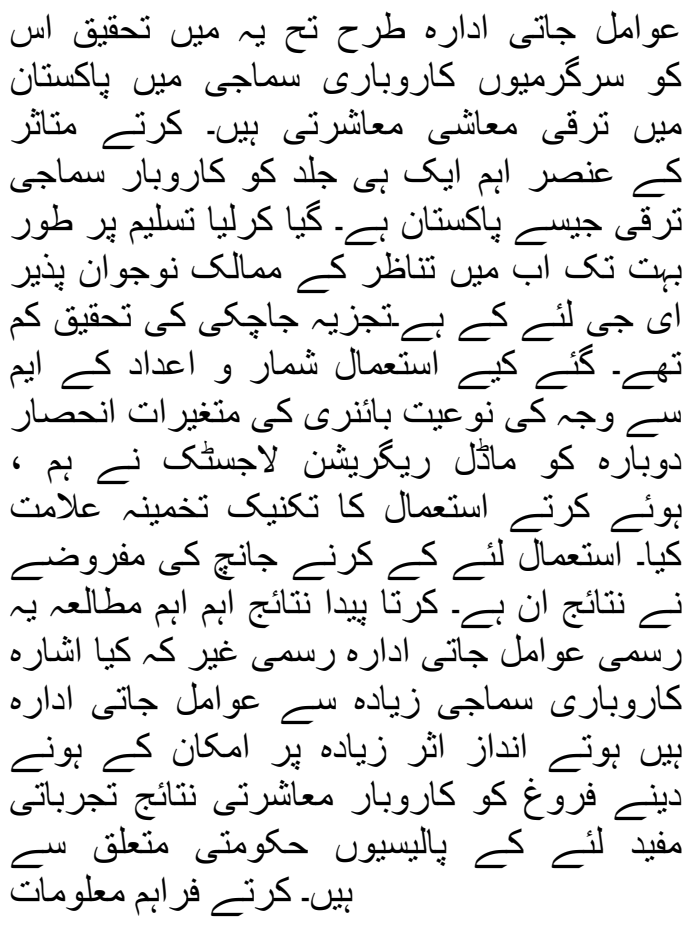

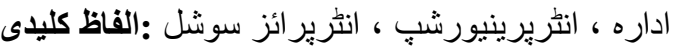
نظريث جاتى اداره ، معاثيات

\footnotetext{
${ }^{10} \mathrm{Ph} . \mathrm{D}$. Scholar, Islamia College Peshawar, Pakistan.

11 Associate Professor, Islamia College Peshawar, Pakistan.

${ }^{12} \mathrm{Ph}$.D. Scholar, Islamia College Peshawar, Pakistan.

${ }^{13}$ Ph.D. Scholar, Islamia College Peshawar, Pakistan.

${ }^{14}$ Ph.D. Scholar, Islamia College Peshawar, Pakistan.
} 


\section{Introduction}

Small and Medium Enterprises play an important role in developing countries' economies development. SMEs are important contributors to employment and economic development (Audretsch \& Keilbach, 2004; Haugh, 2005). SMEs represent $50 \%$ of employment and $90 \%$ of businesses worldwide. While $40 \%$ of GDP in emerging economies are contributed by formal SMEs. However, SMEs growth are greatly subject to the access to finance (Sullivan Mort et al., 2003). For example, in developing economies lack of financing programs from public sector subsidies and loan funds are the main barrier to entrepreneurship development (Dacin, Dacin, \& Tracey, 2011). While in developed economies case high labor cost, intensive competition, and higher taxes are among the main barriers. However, certain large or small barriers can be identified. Therefore, for the country to develop and to achieve high economic growth this entrepreneurship and innovation should be reduced to the minimum (Dwivedi \& Weerawardena, 2018).

Entrepreneurships activities provides opportunity for increase employment level and social-economic wellbeing of the society (Audretsch \& Keilbach, 2004). With this regard a new phenomenon which is based on creation of wealth on social platforms called social entrepreneurship is emerging around the world (Dees, 2007; Martin \& Osberg, 2007). Recently social entrepreneurship have gained attention from research scholars all around the world due to their ability to address pressing global concerns such as; socio-economic development, and environmental development (Corner \& Ho, 2010; Dees, 2007; Peredo \& McLean, 2006; Weerawardena \& Mort, 2006). So far most of the available literature on social entrepreneurship has focus personal characteristics (Dees, 2007), experiences (Certo \& Miller, 2008), and success factors (Noruzi et al., 2010). This can be divided into two concepts that has been used frequently in previous studies. One hand many important studies are focused on the social entrepreneurship meaning and many studies investigated using case study. (Dacin et al., 2011) stated that there is a lack of formal rigorous methods and hypothesis in social entrepreneurship area. Less attention has been devoted so far in the relationships in the social entrepreneurship (Dwivedi \& Weerawardena, 2018). There is still very few known studies available in the context of institutional factors that affect the entrepreneurial activities (Abu-Saifan, 2012; Noruzi et al., 2010) particularly in young developing economies like Pakistan. Therefore, it is essential to know how institutional factors both formal and informal affect transnational entrepreneurship development in Pakistan.

The rest of the paper is organized as follows. In the next section the relevant literature is discussed and research hypotheses are developed. Follow by the research method. In the next section results are discussed. And the last section conclude summary of the study and discussed limitations as well as suggestions for future research in the area.

\section{Literature review}

\section{Conceptualizing Social entrepreneurship}

Social entrepreneur defined mostly in available literature with respect to core characteristics of individual, like, mission leader \& persistent (Martin \& Osberg, 2007), social value creator (Sullivan Mort et al., 2003), energetic (Short, Moss, \& Lumpkin, 2009), highly accountable (Dees, 2007), change agent \& dedicated (Shane \& Venkataraman, 2000), opinion leader (Martin \& Osberg, 2007), manager, leader (Short et al., 2009), and as a initiator (Certo \& Miller, 2008). While traditional entrepreneur defined by various researcher with respect to its core characteristics, as innovator by (Audretsch \& Keilbach, 2004), Risk taker \& high achiever (Boschee, 1995), strategic thinker (Haugh, 2005), as leader, holistic \& committed (Nicholls, 2008). This reflect social entrepreneurship as individual business activity. However, according to (Abu-Saifan, 2012), this generalization to accept still not enough, he stated entrepreneurship as extended activity which best performed by a group of people or team. However, due to the lack of theoretical level definition, the only prospect in literature which make differentiate in both terminologies are based on primary profitoriented purpose.

The new domains such as social innovations, and non-profit management organizations that interact with the concern phenomena was elaborated first by (Peredo \& McLean, 2006), they describe social entrepreneurship as new way to achieve economic success, it represents next transformation of business thinking. Information communication technology (ICT), make new ways for business organization to communicate their product or services directly to consumer (Aquino, Lück, \& Schänzel, 2018), with new 


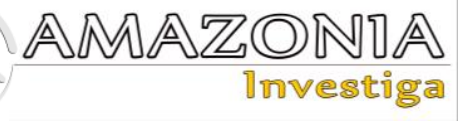

form of business transection (Short et al., 2009). However, (Kshetri, 2007) argued that internet connectivity also helps small business firms to compete and provided opportunities for business (Afridi, Jan, Ayaz, \& Irfan, 2021). With the technological development and emergence of social media networks, the concept of social commerce emerged (Pankomera \& van Greunen, 2019).

The institutional context is key element that have a positive on society's development (Gupta, Chauhan, Paul, \& Jaiswal, 2020). The institutional economic approach argues that entrepreneurial activity has a critical role in environment in (social) (Santos, 2012). Therefore, public support or policies as well as cultural context such as attitudes and beliefs determine the member's behavior and can significantly affect the entrepreneur startup decision (Aquino et al., 2018). In this way institutional environment limits, define and reduce entrepreneurial opportunities which can significantly reduce social entrepreneurial activity rates.

\section{Theoretical Background and Proposed Research Model}

This study used Institutional theory to develop research model. This theory is frequently used in organizational studies and based on resilient aspects of social environment (Dwivedi \& Weerawardena, 2018). Structure process including rules, routines, schemes, and norms which provide guidelines for social behavior. (Short et al., 2009) stated that institutional theory is widely known for that emphasizes isomorphism and legitimacy. In other words institutional theory is policy making that focus on the legal and formal aspects of government structure. (Santos, 2012) stated that in institutional theory organizational norms, structure, and practices are connected to cultural and social environment. Literature have identified many institutional factors that affect social entrepreneurship. It can be mainly divided into formal and informal institutional factors (Shapero \& Sokol, 1982)

\section{Formal institutional factors}

It is difficult to distinction clearly between informal and formal institution as both are mutually dependent. Formal institutions create new opportunities and provide the legal framework for social entrepreneurs. In this way potential social entrepreneurs may be less motivate to take a new starting initiative if faced various financial barriers (Light, 2011). Previous research suggest a larger capital investment is detrimental to entrepreneurship (Corner \& Ho, 2010; Noruzi et al., 2010; Short et al., 2009; Zahra, Rawhouser, Bhawe, Neubaum, \& Hayton, 2008). In both developing and developed many countries a systematic retreat by governments from public goods provision due to the new changing political ideologies give primacy to welfare market-driven models (Certo \& Miller, 2008; Corner \& Ho, 2010; Doherty, Thompson, \& Spear, 2006). Previous research shows capital lays the foundation and is one of the key important to for social entrepreneurs. Further, many studies show the sensitivity of individuals to capital constraints and affect their decision (Audretsch \& Keilbach, 2004; Dees, 1998; Sullivan Mort et al., 2003). However, in existing literature there is no difference between funding access importance for commercial and social entrepreneurs (Short et al., 2009). Further, (Dwivedi \& Weerawardena, 2018) highlighted the existence of financial constraints barriers to which entrepreneurs must cope with to startup. Therefore, this study suggests that reduction in access to finance barriers will positively promote social enterprise projects.

Previous studies shows that level of education has a positive relationship with social entrepreneurial activities (Corner \& Ho, 2010; Noruzi et al., 2010; Zahra et al., 2008). This is because people's are normally guided by their own knowledge and skills (Abu-Saifan, 2012; Certo \& Miller, 2008). Therefore, higher education may have an influence on new social enterprises emergence. Previous studies such as (Corner \& Ho, 2010), noted that citizens likelihood to become social entrepreneurs increases with higher education level. This is probably due to the social networks which they established at university and their perceive commitment to society in the form of sustainable development (Gupta et al., 2020).

H1: Formal institutional factors such as; Access to funding (H1a) and education (H1b) are positively related to social entrepreneurial activities.

\section{Informal institutional factors}

Self-perceived capabilities is the one's ability in order to achieve intended results. However, it consist of many variable such as; perception of entrepreneurial skills, innovativeness, risktaking and role model (Audretsch \& Keilbach, 2004; Weerawardena \& Mort, 2006). The lack of this attribute can affect entrepreneurial activities. 
Self-perceived capabilities explain the participation of social entrepreneur. Therefore, it is expected that self-perceived capabilities have positive relationship with social entrepreneurship. Innovation includes, creativity, novelty, and identify key opportunities to enhance value for consumers as well as producers (Omri, 2020). Although innovation is important factor in competition, however creating innovation may not be that easy (Sila, 2013). Entrepreneurs who own startup businesses are often faced with various difficulties with this regard (Ajao, Oyebisi, \&
Aderemi, 2018). Barriers to innovate can be external such as; opportunities, lack of Government support, covers turbulence and internal such as; high cost and risk, limitations of financial and human resources (Dees, 1998; Dwivedi \& Weerawardena, 2018; Shane \& Venkataraman, 2000).

H2: Informal institutional factors such as; Perceived skills (H2a) and innovativeness (H2b) are positively related to social entrepreneurial activity.

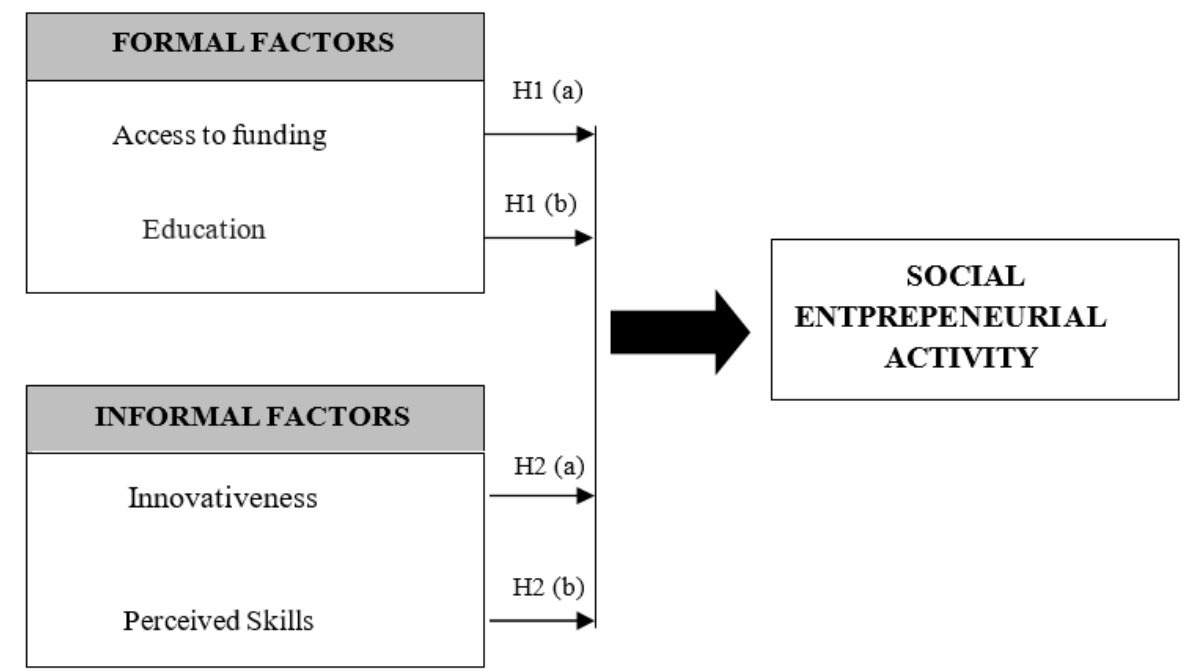

Figure 1. Hypothesized model of the study. Source: the author

\section{Research method}

Previous studies also reported the difficulties in collecting data for social enterprises (Dwivedi \& Weerawardena, 2018). This study used data from Global Entrepreneurship Monitor (GEM), World Bank, and IMF which are main universal databases. Data from GEM specifically the Pakistani NES were used for analysis. The sample size composed of 23.645 observations. Due to the binary nature of the dependent variables, we used logistic regression or probabilities models to test the hypothesis. The model expressed the variables relationship as:

$$
P\left(S E A_{i}=1\right)=\beta_{1} F F_{i}+\beta_{2} I F_{i}+\beta_{3} C V_{i}+\varepsilon_{i}
$$

Ho: $\beta 1,2,3 \neq 0$

Where

$I F_{i}$ the informal factors vector, $F F_{i}$ the formal factors vector. $\varepsilon_{i}$ random disturbance and $C V_{i}$ is a vector for the control variables.

\section{Statistical technique}

Due to the fact that social entrepreneurial activity is a novel and rare activity, application of logit methods or standard probit is not appropriate method. Therefore the ReLogit estimation were used. Multicollinearity diagnostic test and for heteroscedasticity possibility by using robust standard errors the observations autocorrelation were controlled (Rehman et al., 2021).

\section{Results}

Table 1 reported descriptive statistics for the study variables. It can be seen that in Pakistan average social entrepreneurial activity (SEA) is $0.44 \%$ which means percentage of the total adult population between 18 to 60 years. Table 1 shows the mean and standard deviation for all the variables and their significant level. 
Table 1.

Descriptive statistics results SPSS. Source: the author

\begin{tabular}{|c|c|c|c|c|c|}
\hline Study variables & $\mathbf{M}$ & SD & 1 & 2 & 3 \\
\hline Social entrepreneurship & 0.004 & 0.04 & 1.00 & & \\
\hline Innovativeness & 3,012 & 0.3 & $0,03 * * *$ & 1,00 & \\
\hline Skills perceived & 4,331 & 1.9 & $0,04 * * *$ & $0,04 * * *$ & 1,00 \\
\hline Access to funding & 0,423 & 0.7 & $-0,03 * * *$ & $0,02 * * *$ & $-0,06 * * *$ \\
\hline Education & 0,486 & 0.5 & $0,06 * * *$ & 0,01 & $0,19 * * *$ \\
\hline Gender & 0.693 & 0.6 & $0.01 *$ & 0.00 & $0.05 * * *$ \\
\hline Age & 36.152 & 9.29 & $-0.01 * * *$ & $-0.01 * * *$ & $-0.12 * * *$ \\
\hline GDP & 12.343 & 0.76 & 0.01 & $-0.04 * * *$ & $0.01 * * *$ \\
\hline Variables & 4 & 5 & 6 & 7 & 8 \\
\hline Innovativeness & 1,00 & & & & \\
\hline Skills perceived & $-.22 * * *$ & 1,00 & & & \\
\hline Gender & $-.07 * * *$ & $.14 * * *$ & 1,00 & & \\
\hline Age & $-.02 * *$ & $-.04 * * *$ & $-.03 * * *$ & 1,00 & \\
\hline GDP & $-.04 * * *$ & $.03 * * *$ & .00 & -.01 & 1,00 \\
\hline
\end{tabular}

The ReLogit regression results for both formal and informal institutional factors are shown in table 2. Further table 4 shows that the percentage is greater than $99 \%$ for all models which is correctly predicted. Model A shows The ReLogit results for the control variables and formal institutional factors. The results for control variables and informal institutional factors are shown in Model B. While Model C shows the full results for informal and formal institutional factors.

Model A measure demographic variables such as age, gender, age squared, and as a macro variable GDP natural logarithm. The findings are in line with the current literature which suggest that it is important to consider socio-demographic characteristics of individual's to understand the likelihood of social entrepreneur. Moreover, the findings revealed that probability of becoming a social entrepreneur increases with more access to funding. However, in case of institutional factor education the results is not statistically significant. For control variables the current literature shows the probability increases form man as compared to female of becoming social entrepreneur. This finding is also in line with the current studies (Rawhouser et al., 2019). However, the coefficient for the aged square is negative which indicate that social entrepreneur likelihood at peaks.at early age and decreases thereafter.

Table 2.

Rare events logit models output results. Source: the author

\begin{tabular}{|c|c|c|c|c|c|c|}
\hline & Model A & & Model B & & Model C & \\
\hline & $\mathrm{dF} / \mathrm{dx}$ & $\begin{array}{l}\text { Robust. Std. } \\
\text { Err }\end{array}$ & $\mathrm{dF} / \mathrm{dx}$ & Robust. Std. Err & $\mathrm{dF} / \mathrm{dx}$ & $\begin{array}{l}\text { Robust. } \\
\text { Std. Err }\end{array}$ \\
\hline \multicolumn{7}{|l|}{ Formal Factors } \\
\hline Access to funding & $1.32 * * *$ & $(0.41)$ & & & $1.41 * * *$ & $(0.26)$ \\
\hline Education & 0.20 & $(0.37)$ & & & 0.13 & $(0.08)$ \\
\hline \multicolumn{7}{|l|}{ Informal Factors } \\
\hline Innovativeness & & & $-0.59 * * *$ & $(0.20)$ & $-0.57 * * *$ & $(0.20)$ \\
\hline Skills perceived & & & $1.91 * * *$ & $(0.24)$ & $1.82 * * *$ & $(0.24)$ \\
\hline \multicolumn{7}{|l|}{ Control Variables } \\
\hline Gender & $0.29 *$ & $(0.17)$ & 0.08 & $(0.15)$ & $0.36 *$ & $(0.18)$ \\
\hline Age & $0.14 * * *$ & $(0.05)$ & $0.11 * *$ & $(0.05)$ & $0.09 *$ & $(0.05)$ \\
\hline $\mathrm{Age}^{2}$ & $-0.00 * * *$ & $(0.00)$ & $-0.00 * * *$ & $(0.00)$ & $-0.00^{* *}$ & $(0.00)$ \\
\hline GDP & 0.07 & $(0.07)$ & 0.02 & $(0.13)$ & 0.04 & $(0.09)$ \\
\hline Number of obs. & 23.645 & & 23.645 & & & 23.645 \\
\hline
\end{tabular}

Model B shows the informal factors impact the coefficients for perception of entrepreneurial skills and innovativeness are significant. As it was expected, the first negative and the other 
positive. The age coefficient is lower than in Model A and the GDP and gender are not significant.

Lastly, in the Model C shows the combine institutional factors coefficients, controlling for age, gender, and GDP. For the formal institution factors the results support $\mathrm{H} 1$ (a) that increase funding access increase social entrepreneur activities. However, regarding education in contract no support for the H1 (b). The relationship is not statically significant. For informal institutional factors the results support for H2 (a). However, a change in this kind of perception to stimulate by taking into account the current pandemic situation and restriction on business activities. The H2 (b) also supported

Table 3.

Marginal effects. Source: the author which is entrepreneurial skills is positively related to social entrepreneur activity. However, (Noruzi et al., 2010) argued that governmental programs cannot be affect this change and must be done through cultural and social factors like perception, attitude and risk profiles.

Table 3 shows the median values of marginal effects for selected variables. For being a social entrepreneur the base line probability is $0.26 \%$. Change in education level, and access to funding only adds $0.04 \%$ to $0.65 \%$ of minimum to maximum value. The results indicated that informal factors are more significant for social entrepreneurship than formal institutional factors.

\begin{tabular}{lll}
\hline $\operatorname{Pr}(\mathrm{SEA}=1)$ & & $0.26 \%$ \\
\hline Study variable $(\mathbf{s})$ & Change $(\boldsymbol{\%})$ & predicted probability \\
Funding access & Min to Max value & $0.05 \%$ \\
Innovativeness & 0 to 1 (dummy) & $-0.48 \%$ \\
Perceived Skills & 0 to 1 (dummy) & $0, .67 \%$ \\
\hline
\end{tabular}

\section{Conclusions}

In current knowledge-based economies, the barriers to the development of entrepreneurship and innovation can be related to the lack of sufficient knowledge as many have said it. In most schools and universities for instance in developing countries, the way students are learning is based on the system of "remembering not on thinking". Students are not trained to identify problems around, and think about a solution to them, but trained to remember what has been done by others. This shows a lack of new ideas, less novelty. In other words, Pakistan is rich in natural resources but still, poverty is a challenging issue. How to use, and transform resources need an effective learning system. Additionally, the role played by self-leadership in encouraging innovation cannot be neglected (Afridi, 2021). Due to the funding barrier, an entrepreneur with an innovative idea has many ways to exploit such as: selling ideas or working with others. Social entrepreneurs nowadays operate in a very complex environment (Dwivedi \& Weerawardena, 2018). They face many hurdles in accessing financial and human resources (Zahra et al., 2008). The findings highlighted the importance of institutional factors both formal and informal on social entrepreneurship activities. This study results in particular revealed that informal institutional factors than formal institutional factors are more important and influence the development of social entrepreneurship activities in Pakistan.

This study contribute to the current research in several ways. To promote social entrepreneurial initiatives the results may be helpful in the governmental policies making. Further filling the quantitative studies development gap. Based on institutional economic perspective the quantitative results provide updated information of institutional factors that influence social entrepreneurship.

This study have also some research limitation which is important to be noted. The first limitation is the availability of the updated database to measure process of social entrepreneurship. Second limitation is that this study is based on one country Pakistan. Therefore other context might have differ in results. Future studies if test the institutional factors effects on social entrepreneurship across different countries will enhance our understanding.

\section{References}

Abu-Saifan, S. (2012). Social entrepreneurship: definition and boundaries. Technology innovation management review, 2(2). 


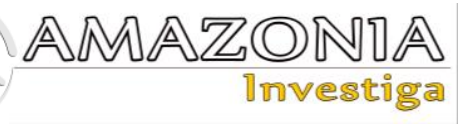

Afridi, F. E. A. (2021). Reconceptualising Selfleadership and Management Style within the Organization. Revista Científica del Amazonas, 4(7), 53-60, https://revistadelamazonas.info/index.php/amaz onas/article/view/45

Afridi, F. E. A., Jan, S., Ayaz, B., \& Irfan, M. (2021). The impact of Covid-19 on E-business practices and consumer buying behavior in a developing country. Amazonia Investiga, 10(38), 97-112,

https://amazoniainvestiga.info/index.php/amazo nia/article/view/1547

Ajao, B., Oyebisi, T., \& Aderemi, H. (2018). Factors influencing the implementation of e-commerce innovations: The case of the Nigerian informal sector. African Journal of Science, Technology, Innovation and Development, 10(4), 473-481.

Aquino, R. S., Lück, M., \& Schänzel, H. A. (2018). A conceptual framework of tourism social entrepreneurship for sustainable community development. Journal of Hospitality and Tourism Management, 37, 23-32.

Audretsch, D., \& Keilbach, M. (2004). Entrepreneurship capital and economic performance. Regional studies, 38(8), 949-959.

Audretsch, D. B., \& Keilbach, M. (2004). Entrepreneurship and regional growth: an evolutionary interpretation. Journal of Evolutionary Economics, 14(5), 605-616.

Boschee, J. (1998). Merging mission and money: A broad member's guide to social eneterpreneurship. National Center for NGO Boards, 32(3), 20-25. https://www.socialent.org/pdfs/MergingMission .pdf

Certo, S. T., \& Miller, T. (2008). Social entrepreneurship: Key issues and concepts. Business horizons, 51(4), 267-271.

Corner, P. D., \& Ho, M. (2010). How opportunities develop in social entrepreneurship. Entrepreneurship theory and practice, 34(4), 635-659.

Dacin, M. T., Dacin, P. A., \& Tracey, P. (2011). Social entrepreneurship: A critique and future directions. Organization science, 22(5), 1203-1213.

Dees, J. G. (1998). The meaning of social entrepreneurship. Kauffman Center for Entrepreneurial Leadership.

Dees, J. G. (2007). Taking social entrepreneurship seriously. Society, 44(3), 24-31.

Doherty, B., Thompson, J., \& Spear, R. (2006). Social entrepreneurship: a different model? International journal of social economics, $33(5 / 6)$,

pp.

$399-410$ https://www.emerald.com/insight/content/doi/10 .1108/03068290610660670/full/html

Dwivedi, A., \& Weerawardena, J. (2018). Conceptualizing and operationalizing the social entrepreneurship construct. Journal of business research, 86, 32-40.

Gupta, P., Chauhan, S., Paul, J., \& Jaiswal, M. P. (2020). Social entrepreneurship research: A review and future research agenda. Journal of business research, 113, 209-229.

Haugh, H. (2005). A research agenda for social entrepreneurship. Social enterprise journal, 1(1), pp.

$1-12$

https://www.emerald.com/insight/content/doi/10 .1108/17508610580000703/full/html

Kshetri, N. (2007). Barriers to e-commerce and competitive business models in developing countries: A case study. Electronic Commerce Research and Applications, 6(4), 443-452.

Light, P. C. (2011). The search for social entrepreneurship. Strategic Direction, 27(6). https://www.emerald.com/insight/content/doi/10 $.1108 / \mathrm{sd} .2011 .05627$ fae.001/full/html

Martin, R. L., \& Osberg, S. (2007). Social entrepreneurship: The case for definition. Stanford social innovation review Stanford. https://www.ngobiz.org/picture/File/Social\%20 Enterpeuneur-

The \%20Case \%20of\%20Definition.pdf

Nicholls, A. (2008). Social entrepreneurship: New models of sustainable social change. OUP Oxford.

Noruzi, M. R., Westover, J. H., \& Rahimi, G. R. (2010). An exploration of social entrepreneurship in the entrepreneurship era. Asian Social Science, 6(6), 3.

Omri, A. (2020). Formal versus informal entrepreneurship in emerging economies: The roles of governance and the financial sector. Journal of business research, 108, 277-290.

Pankomera, R., \& van Greunen, D. (2019). Opportunities, barriers, and adoption factors of mobile commerce for the informal sector in developing countries in Africa: A systematic review. The Electronic Journal of Information Systems in Developing Countries, 85(5), e12096. Peredo, A. M., \& McLean, M. (2006). Social entrepreneurship: A critical review of the concept. Journal of world business, 41(1), 56-65. Rawhouser, H., Cummings, M., \& Newbert, S. L. (2019). Social impact measurement: Current approaches and future directions for social entrepreneurship research. Entrepreneurship theory and practice, 43(1), 82-115.

Rehman, A., Ishaque, A., Malik, S., Rehman, S. U., Hussain, A., Khan, M., Afridi, F. E. A. (2021). Exploring Asymmetric Nexus Between Tourism, Economic Growth and $\mathrm{CO} 2$ Emissions in the 
Context of Pakistan. International Journal of Energy Economics and Policy, 11(3), 338-345.

Santos, F. M. (2012). A positive theory of social entrepreneurship. Journal of Business Ethics, 111(3), 335-351.

Shane, S., \& Venkataraman, S. (2000). The promise of entrepreneurship as a field of research. Academy of Management review, 25(1), 217-226.

Shapero, A., \& Sokol, L. (1982). The social dimensions of entrepreneurship. Encyclopedia of entrepreneurship. Englewood Cliffs: PrenticeHall, 72-90.

Short, J. C., Moss, T. W., \& Lumpkin, G. T. (2009). Research in social entrepreneurship: Past contributions and future opportunities. Strategic entrepreneurship journal, 3(2), 161-194.
Sila, I. (2013). Factors affecting the adoption of B2B e-commerce technologies. Electronic Commerce Research, 13(2), 199-236.

Sullivan Mort, G., Weerawardena, J., \& Carnegie, K. (2003). Social entrepreneurship: Towards conceptualisation. International journal of nonprofit and voluntary sector marketing, 8(1), 76-88.

Weerawardena, J., \& Mort, G. S. (2006). Investigating social entrepreneurship: A multidimensional model. Journal of world business, 41(1), 21-35.

Zahra, S. A., Rawhouser, H. N., Bhawe, N., Neubaum, D. O., \& Hayton, J. C. (2008). Globalization of social entrepreneurship opportunities. Strategic entrepreneurship journal, 2(2), 117-131. 